\title{
Pathology of heart and skeletal muscle inflammation (HSMI) in farmed Atlantic salmon Salmo salar
}

\author{
R. T. Kongtorp ${ }^{1, *}$, T. Taksdal ${ }^{1}$, A. Lyngøy ${ }^{2}$ \\ ${ }^{1}$ National Veterinary Institute, Oslo, Norway \\ ${ }^{2}$ Nordvest fiskehelse A/S (North West Fish Health Ltd), Gurskøy, Norway
}

\begin{abstract}
This is the first description of heart and skeletal muscle inflammation (HSMI), a novel disease affecting farmed Atlantic salmon Salmo salar in Norway. HSMI was first diagnosed in 1999, and there has since been a yearly increase in the number of recorded outbreaks. Atlantic salmon are commonly affected 5 to 9 mo after transfer to sea, but outbreaks have been recorded as early as $14 \mathrm{~d}$ following seawater transfer. Affected fish are anorexic and display abnormal swimming behaviour. Autopsy findings typically include a pale heart, yellow liver, ascites, swollen spleen and petechiae in the perivisceral fat. While mortality is variable (up to $20 \%$ ), morbidity may be very high in affected cages. Until more accurate tests are available, HSMI is diagnosed on the basis of histopathology. The major pathological changes occur in the myocardium and red skeletal muscle, where extensive inflammation and multifocal necrosis of myocytes are evident. HSMI is transmissible and, although most likely caused by a virus, the causal agent has not yet been isolated. This paper describes clinical signs and pathology of HSMI from 3 field outbreaks in Norway. Microscopic lesions are compared and discussed in relation to published descriptions of pancreas disease (PD) and cardiomyopathy syndrome (CMS). It is concluded that HSMI is histopathologically distinguishable from PD and CMS.
\end{abstract}

KEY WORDS: Heart and skeletal muscle inflammation - HSMI - Atlantic salmon - Myocarditis · Myositis

Resale or republication not permitted without written consent of the publisher

\section{INTRODUCTION}

Heart and skeletal muscle inflammation (HSMI) is a novel disease in farmed Norwegian Atlantic salmon Salmo salar. HSMI was first diagnosed in 1999, and has since become an increasing problem in Norwegian salmon farms. Salmon are commonly affected 5 to 9 mo after transfer to sea, but outbreaks have been recorded as early as $14 \mathrm{~d}$ following seawater transfer. Affected fish are anorexic and display abnormal swimming behaviour. Autopsy findings typically include a pale heart, yellow liver, ascites, swollen spleen and petechiae in the perivisceral fat. Diagnosis of HSMI is presently based on histological examination. HSMI is characterised by extensive panmyocarditis and myositis, particularly involving red skeletal muscle. Morbidity may be very high, while mortalities are variable and may reach $20 \%$ in affected cages. Environmental stress during an outbreak seems to increase mortalities (A.
Lyngøy unpubl. data). HSMI is experimentally transmissible to healthy Atlantic salmon by intraperitoneal injection with affected cardiac tissue and by cohabitation with injected fish (R. T. Kongtorp et al. 2004).

Myocarditis and myopathy have previously been described in pancreas disease (PD) (Ferguson et al. 1986, Rodger et al. 1991, 1994, Murphy et al. 1992, McLoughlin et al. 1995, 1996, 1997, 2002), and in cardiomyopathy syndrome (CMS) (Ferguson et al. 1990, Rodger \& Turnbull 2000).

Outbreaks of PD have been reported from Scotland (Munro et al. 1984), USA (Kent \& Elston 1987), Norway (Poppe et al. 1989), Ireland (Murphy et al. 1992), France and Spain (Raynard et al. 1992). PD is caused by salmon pancreas disease virus (SPDV) (Nelson et al. 1995), characterised as an alphavirus (Weston et al. 1999). SPDV is closely related to sleeping disease virus (SDV) of farmed rainbow trout Oncorhynchus mykiss (Castric et al. 1997, Villoing et al. 2000a,b). 
CMS was first described in Norway (Ferguson et al. 1990), and subsequently in the Faeroe Islands (Bruno \& Poppe 1996) and Scotland (Rodger \& Turnbull 2000). The causality of CMS is unclear, but Grotmol et al. (1997) described nodavirus-like particles in association with heart lesions consistent with CMS in Norway.

As the causal agent has not yet been found, it is important to establish a protocol for distinguishing HSMI histologically from other muscular disorders of Atlantic salmon. In this paper we describe the clinical signs, gross pathology and major histopathological findings from 3 field outbreaks of HSMI in Atlantic salmon during 1999 and 2003, and compare and discuss these features in relation to previously published descriptions of PD and CMS.

\section{MATERIALS AND METHODS}

Field samples. Atlantic salmon were sampled during disease outbreaks in a seawater farm on the Norwegian west coast in July 1999 and on 2 different locations in western Norway in May and June 2003. Clinically diseased and dead fish were sampled nonrandomly, whereas asymptomatic fish were collected randomly from affected cages. Fish sampled from the 1999 outbreak were killed by a blow to the head before blood samples were collected from the caudal vein, and macroscopic changes were recorded before tissues were sampled for histology. Fish sampled from the 2003 outbreaks were euthanised at the fish farm and sent on ice to the National Veterinary Institute (NVI), Oslo, where autopsy and sampling for histological examination took place $1 \mathrm{~d}$ after euthanasia.

Histology. Tissue samples were obtained from gills, heart, skeletal muscle, mid-kidney, spleen and pyloric caeca with pancreatic tissue, and fixed in $10 \%$ neutral phosphate buffered formalin. Samples from skeletal muscle consisted of longitudinal and transverse sections of the area ventral to the dorsal fin and adjacent to the lateral line, including red and white muscle tissue. Formalin fixed samples were prepared for histological examination by standard paraffin wax techniques and stained with haematoxylin and eosin (H\&E).

Microbiological examination. Kidney swabs were streaked onto blood agar supplemented with $2 \% \mathrm{NaCl}$ and incubated at $15^{\circ} \mathrm{C}$ for $7 \mathrm{~d}$.Kidney swabs from the 2003 outbreak were also streaked onto blood agar and incubated at $20^{\circ} \mathrm{C}$ for $7 \mathrm{~d}$. Kidney samples were also tested for infectious salmon anaemia virus (ISAV) by an indirect fluorescent antibody technique (IFAT) (Falk \& Dannevig 1995). Kidney and myocardial tissues from the 1999 outbreak were inoculated onto Chinook salmon embryo (CHSE-214) (Lannan et al. 1984), Blue-gill fry (BF-2) (Wolf \& Quimby 1966) and epithelioma papillosum cyprini (EPC) (Fijan et al. 1983) cell cultures according to standard procedures at the NVI. Mid-kidney material from the 2003 outbreak was inoculated onto BF-2 and EPC cell cultures. The material was passaged after $1 \mathrm{wk}$ and incubated for an additional week.

Challenge study. Homogenates of mid-kidney from the 1999 outbreak were injected intraperitoneally into 20 Atlantic salmon. Injected salmon were placed in a tank of dechlorinated freshwater together with 20 noninjected fish (cohabitants). On commencement of the experiment, the fish had a mean weight of $25 \mathrm{~g}$. The water flow was $90 \mathrm{l} \mathrm{h}^{-1}$, and the average temperature was $12^{\circ} \mathrm{C}$. Challenged fish were observed for $7 \mathrm{wk}$. At the end of the experiment, heart samples were prepared for histology as described above.

\section{RESULTS}

\section{Clinical signs}

The most prominent signs of disease in the sea cages were anorexia and abnormal swimming behaviour. During the 1999 disease outbreak, there was an initial decrease in appetite and mortalities varying from 4 to $15.5 \%$ prior to sampling. Peracute mortalities similar to those observed in outbreaks of CMS were also seen. During the 2003 disease outbreaks, anorexia was not as evident. In the first of these outbreaks, mortality had been recorded as negligible when HSMI was first diagnosed 3 mo prior to sampling, but slowly increasing in the mo before fish were collected for the present study. The second 2003 outbreak had negligible cage mortality when HSMI was diagnosed 2 wk before the study samples were taken. One wk prior to sampling the mortality suddenly rose to $20 \%$ in cages with affected fish. Fish with abnormal swimming behaviour were dark and lethargic, typically positioned near the cage wall and facing the sea current. The fish retained normal balance, but did not respond to feeding or other stimuli.

\section{Gross pathology}

Five clinically diseased and 15 asymptomatic fish were sampled from the 1999 outbreak. In the 2003 outbreaks, 5 dead and 10 asymptomatic fish were examined. There were no evident differences between the 3 groups of clinically diseased, dead or asymptomatic fish. All were in good condition but with no gut contents. There were no obvious external lesions. Of the 35 fish sampled, 21 had a pale or greyish heart (Fig. 1A,B). The pericardial cavities of 15 of these fish contained small amounts of haemorrhagic fluid or 

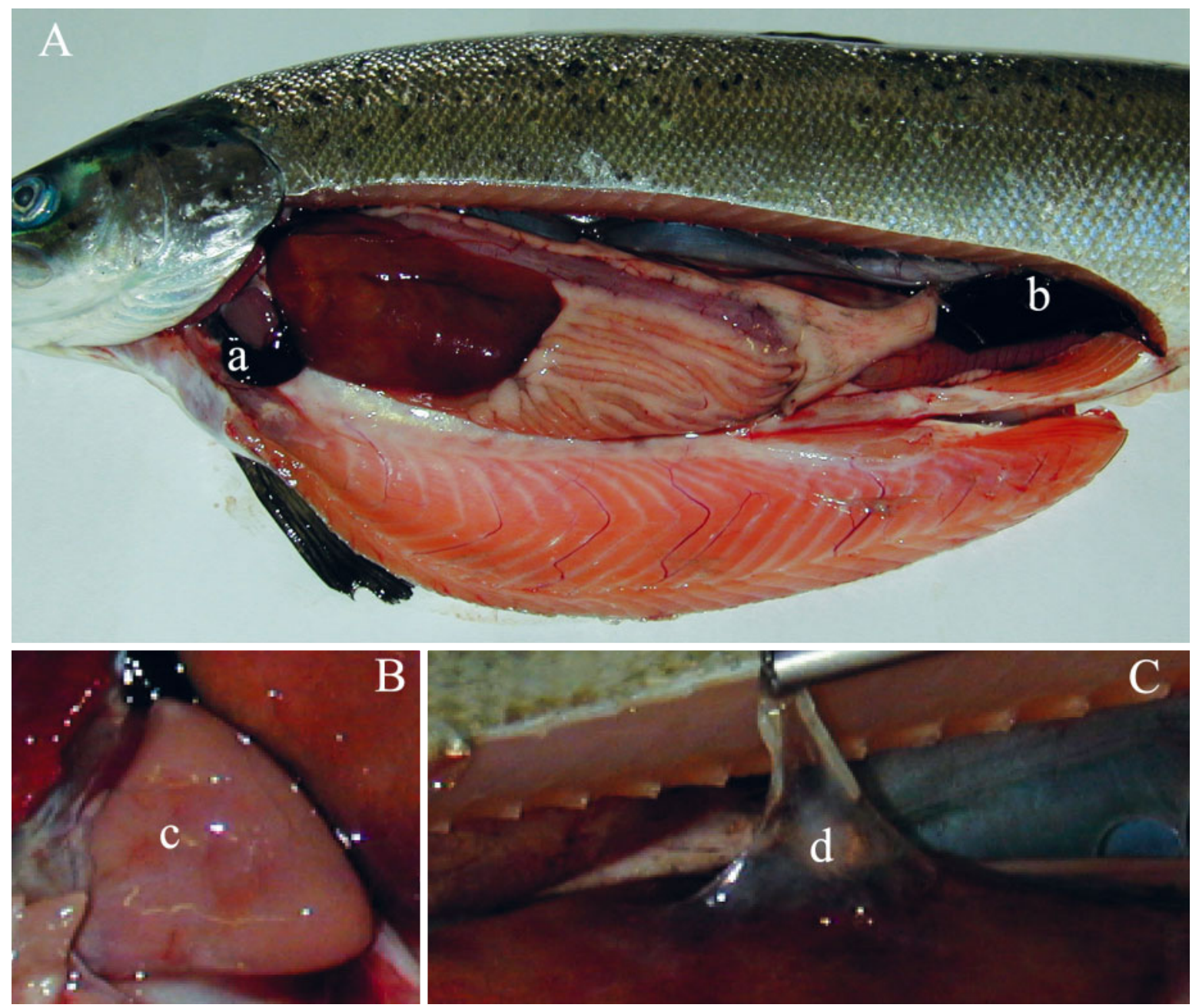

Fig. 1. Salmo salar. Macroscopical findings in heart and skeletal muscle inflammation (HSMI). (A) In this salmon, the heart is pale and there is haemopericardium. The spleen appears swollen. (B) Closer picture of a pale heart. (C) A few fish had a fibrinous layer on the liver. a: haemopericardium, b: spleen, c: heart, d: fibrinous layer

coagulum. Small amounts of ascitic fluid were seen in 8 fish. Petechiae were observed in the perivisceral fat of 10 fish. The liver was pale or yellowish in 20 fish and stained brown in 6 fish. A fibrinous coat was present on the surface of the livers of 5 fish (Fig. 1C). In 15 fish the spleen was swollen. Gross pathology of the skeletal muscle was sparse, but in 3 fish the muscular layer appeared loose. Of asymptomatic fish sampled from the 1999 outbreak, 3 had no macroscopic lesions.

\section{Histopathology}

Heart

HSMI was recognised by an extensive panmyocarditis that was a consistent finding in the 10 clinically diseased and dead fish. Twelve of 15 asymptomatic fish sampled in 1999 and all 10 sampled in 2003 displayed panmyocarditis.

A severe epicarditis, characterised by a massive infiltration of mononuclear cells, was present in 34 fish (Fig. 2A). Deposits of fibrinous material in the epicardium were observed in 4 fish.

A range of histological changes was present in the hearts of affected fish. The most common lesions were ventricular, in which both the spongy and compact layers were infiltrated by mononuclear cells, comprising macrophages, lymphocyte- and plasma-like cells (Fig. 2B). The inflammatory cells were localised within and around myocytes in a diffuse or focal pattern, most evident in the compact layer. In 3 mildly affected fish, cellular infiltrates were seen only in association with vessels in the compact myocardium, and in 2 fish lesions were restricted to the interface between the spongy and compact layers. Nine moderately affected 

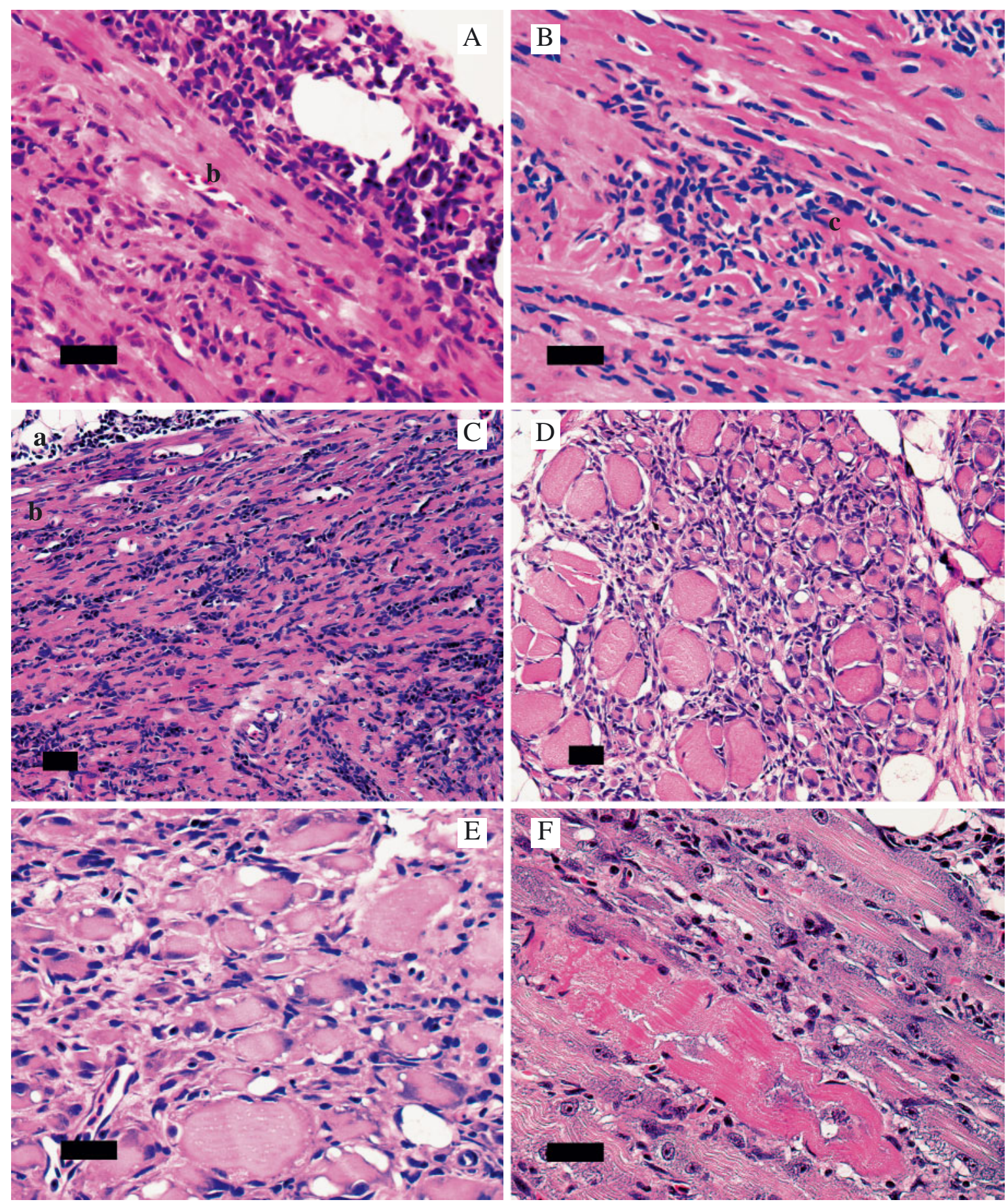

Fig. 2. Salmo salar. Micrographs of sections from affected fish (H\&E). (A) Ventricle showing severe epicarditis and myocarditis in the underlying compact myocardium. (B) Focal cellular infiltration in the compact myocardium. (C) Severe, diffuse myocarditis in the compact myocardium. (D) Cross section of red skeletal muscle, featuring severe myositis. (E) Vacuolisation and degeneration of red skeletal muscle fibres. Infiltration of mononuclear cells. (F) Longitudinal section of red skeletal muscle. The muscle fibres show signs of degeneration. a: epicardium, b: compact myocardium, c: focal cellular infiltration. Scale bars $=20 \mu \mathrm{m}$

hearts were focally hypercellular (Fig. 2C). In 20 severe cases, cellular infiltration was diffuse and extensive, and a large number of necrotic myocytes were observed (Fig. 2B).
Affected myocytes exhibited signs of degeneration with condensation, eosinophilia, loss of muscle striation, vacuolation and central nuclei. Several cells were also undergoing pyknosis or karyolysis. Necrotic cells 
appeared in association with inflammatory infiltrates. Hypertrophic nuclei could be observed in a few myocytes within the spongy muscle layer. Endocardial cells were also multifocally hypertrophic, appearing most often adjacent to myocyte inflammation.

\section{Skeletal muscle}

Three fish with mild cardiac lesions did not have any lesions in the skeletal muscle, while 31 fish with moderate or severe heart lesions also had lesions in the skeletal muscle. In the latter individuals the red skeletal muscle was hypercellular, with mononuclear cells within and between muscle fibres (Fig. 2D). Loss of striation, eosinophilia and vacuolation of myocytes were present, and single cells were necrotic (Fig. 2E,F). White muscle was mildly affected in 13 fish. Single white fibres were degenerative, with no visible inflammation. In 5 cases, the inflammation extended to white fibres adjacent to affected red fibres. There were no lesions in scales or skin.
Liver

Multifocal necrosis of hepatocytes was found in 15 fish displaying severe panmyocarditis. There was no evident pattern to the necrotic foci, and they varied in size and shape (Fig. 3A). Affected cells were vacuolated and pyknotic or karyolytic (Fig. 3B). Phagocytosis of normal hepatocytes was associated with necrotic foci. There was no prominent cellular response to the hepatocytic lesions.

\section{Other organs}

Pancreatic lesions were not observed (Fig. 3C). Focal haemorrhage and accumulation of erythrocytes was observed in the kidney, spleen and gills of 7 fish. The splenic parenchyma of 16 fish also appeared pseudolobulated (Fig. 3D). Moderate to severe peritonitis was present in all 35 fish. Macrophage-like cells with a hyaline-like eosinophilic content were observed in
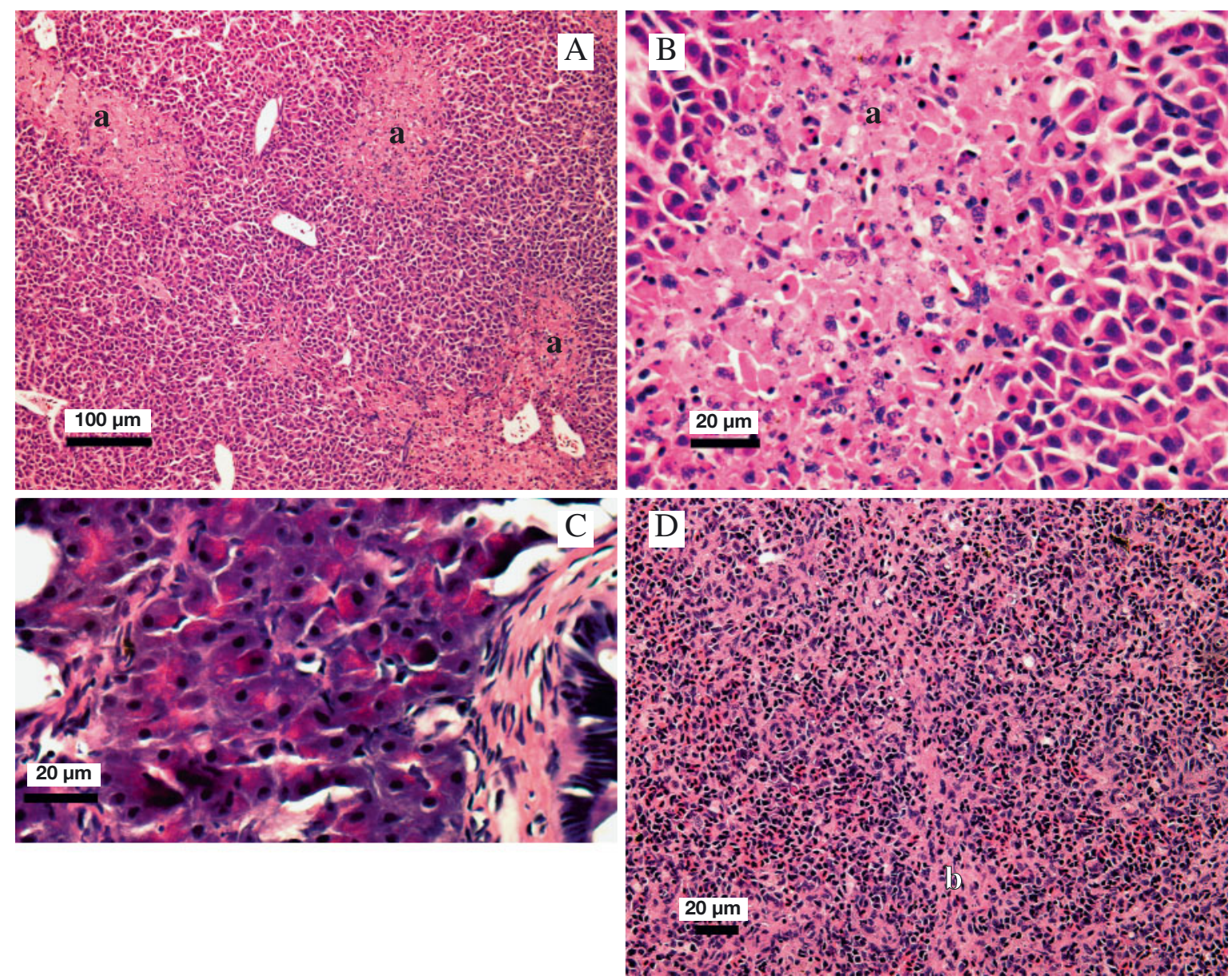

Fig. 3. Salmo salar. Micrographs of sections from affected fish (H\&E). (A) Multifocal hepatocyte necrosis in fish with severe myocardial lesions. (B) Necrotic focus in the liver. (C) Intact acinar pancreatic tissue in HSMI diseased fish. (D) Pale-coloured cells create pseudolobulation of the spleen. a: necrotic foci, b: splenic pseudolobulation 
these lesions. Similar cells have been associated with vaccine-induced peritonitis (Poppe \& Breck 1997). Epitheliocystis-like epithelial inclusions and Ichtyobodo necator (Costia) were observed in the gills of 20 fish.

\section{Microbiological examination}

Pericardial samples from 1 of 4 asymptomatic fish with pale hearts showed sparse growth on blood agar with $2 \% \mathrm{NaCl}$. The cultures were identified as a Vibrio sp. Four kidney samples from clinically diseased and 8 from asymptomatic fish did not reveal any bacteriological growth on blood agar with or without $2 \% \mathrm{NaCl}$.

There was no evident cytopathic effect in any of the cell cultures incubated with tissue material from 10 asymptomatic fish with myocarditis. IFAT tests on kidney imprints from 17 fish were negative for ISAV.

\section{Challenge study}

None of the 20 fish showed clinical signs of disease during the experiment. On histological examination, 1 injected fish displayed epicarditis. There were no cardiac lesions in the remaining fish.

\section{DISCUSSION}

This study describes the clinical and histopathological features of HSMI for the first time. The pathological findings presented correlate with typical observations during other field outbreaks of HSMI (R. T. Kongtorp \& A. Lyngøy pers. obs). The morbidity was remarkably high in asymptomatic fish. At autopsy, the most common finding was a pale heart, possibly due to a severe epicarditis. Histopathologically, heart and red skeletal muscle appeared to be most severely affected, showing a severe inflammation of myocytes that was consistent in the myocardium and common in skeletal muscle. Indications of myocyte damage, including loss of striation, eosinophilia and necrosis, were also present. While lesions were restricted to heart and skeletal muscle in mild and moderate HSMI, they were more widespread in severe cases. Multifocal liver necrosis was present in under half of the fish diagnosed with HSMI, and accumulation of erythrocytes was observed in the gills, spleen and kidney of approximately $20 \%$ of the fish under study.

The panmyocarditis found in Atlantic salmon with HSMI was remarkably extensive. We suggest, therefore, that a putative agent causing HSMI must be present in the myocardium at some stage in the pathogenesis, thus inducing an immune response. The con- sistency of cardiac involvement further supports this hypothesis. When present, the severity of myositis in red muscle appears to correlate with the degree of cardiac pathology. It is not clear whether the inflammation or myocyte degeneration is the primary response in outbreaks of HSMI. When diagnosed in the field, inflammation is the most evident component of the muscle histopathology. It is likely, however, that myocytes degenerate prior to the infiltration of inflammatory cells. A causal agent could possibly induce degeneration primarily, while the massive cellular infiltration may occur secondarily in an attempt to remove damaged cells from the affected area. Alternatively or simultaneously, the severe inflammation itself may induce myocyte degeneration and necrosis in unaffected myocytes. A sequential field study may provide more understanding of the pathogenesis of HSMI.

The role of hepatocytes in this disease is uncertain, but the magnitude of hepatocyte damage is likely to affect homeostasis or vice versa. Hepatocyte necrosis is, however, likely to be a secondary effect of the cardiac pathology, as no inflammatory response can be detected in association with the hepatic lesions. General tissue involvement is probably also an effect of circulatory disturbance. The splenic pathology in HSMI may result from a reaction to the massive release of leucocytes into the bloodstream, but the cause of this pattern is only speculative.

The investigations conducted in this study indicate that the morbidity of an outbreak is much higher than its clinical appearance. Random sampling of salmon from affected sea cages revealed a high frequency of asymptomatic individuals with moderate to severe histopathological changes. This has also been described for cardiac diseases of several mammalian species, where lesion severity is not always correlated to clinical signs (Carlton \& McGavin 1995). The magnitude of damage required to cause mortality in HSMI is unclear. Stress factors that are known to reduce disease resistance may play a critical role in the outcome of the disease. There have been some reports of particularly high mortality of HSMI in association with management stresses such as delousing and grading (A. Lyngøy pers. obs.). Sudden deaths may occur due to heart failure in such stressful situations because of extensive myocardial damage.

Results from diagnostic examinations and transmission experiments (R. T. Kongtorp et al. 2004), suggest that HSMI is an infectious disease. These studies indicate that HSMI is likely to be caused by a virus. No known viruses have been isolated using standard diagnostic methods at NVI, and we suggest therefore that a novel pathogenic virus causes HSMI. Although the incubation period of cell cultures used in the present study was probably too short to rule out the presence of 
Table 1. Histopathological lesions appearing in heart and skeletal muscle inflammation (HSMI), pancreas disease (PD) and cardiomyopathy syndrome (CMS) in Atlantic salmon

\begin{tabular}{|lcccc}
\hline Lesions & HSMI & PD & CMS \\
\hline Epicarditis & + & + & + \\
$\begin{array}{l}\text { Myocarditis and degeneration of } \\
\text { compact myocardium }\end{array}$ & + & + & - \\
$\begin{array}{l}\text { Myocarditis and degeneration of } \\
\text { spongy myocardium }\end{array}$ & + & + & + \\
$\begin{array}{l}\text { Skeletal muscle inflammation and } \\
\text { degeneration }\end{array}$ & + & + & - \\
$\begin{array}{l}\text { Multifocal necrosis of hepatocytes } \\
\text { Necrosis of exocrine pancreas }\end{array}$ & + & - & $+/-$ \\
\hline
\end{tabular}

SPDV, histological examination does not support a PD diagnosis. The negative results from the challenge experiment in the present study could be explained by the short experimental period. Other explanations could be that the inoculating material was prepared from fish that were past the infectious stage of pathogenesis, that a failure occurred in the preparation method or that the study was conducted in freshwater. In the field, HSMI has only been reported during the seawater stage. However, pancreatic necrosis has been successfully transmitted to salmon in freshwater as early as $4 \mathrm{~d}$ postinjection with PD homogenate (Boucher et al. 1995, Murphy et al. 1995), and fish presented pancreatic changes up to 13 wk after challenge (Houghton 1994).

Whether HSMI is a new disease in its own right or a variant expression of a known agent is not clear at this stage. The lesions associated with HSMI are partly similar to those exhibited in PD and CMS (Table 1). Thus, it may be difficult to distinguish between the 3 diseases. Both PD and HSMI occur most commonly within the first year in seawater (McLoughlin et al. 2002). CMS often affects older salmon, usually 14 to 18 mo after sea transfer (Ferguson et al. 1990). A characteristic feature of CMS is sudden death with little evidence of clinical disease. This was also seen in the 1999 HSMI outbreak, but is a rather uncommon occurrence in field outbreaks (A. Lyngøy pers. obs.). Mortality is highly variable in both PD (Crockford et al. 1999) and HSMI. Following an outbreak of PD, however, up to15\% of the survivors fail to grow (Munro et al. 1984). This has not been observed in association with HSMI.

Histopathological changes in the compact ventricular myocardium are consistent in both PD and HSMI. In PD the compact myocardial necrosis is described as a focal degenerative myopathy, and appears in the early stages of disease (Ferguson et al. 1986, Murphy et al. 1992, McLoughlin et al. 1995). Massive, usually diffuse, mononuclear cell infiltration is clearly evident in HSMI cases. Lesions attributed to CMS are typically restricted to the spongy myocardium (Ferguson et al.
1990). In the spongy portion of the ventricle and the atrium, the pathologic changes in HSMI, PD and CMS are similar, and are not easily distinguished. In the event of simultaneous occurrence of CMS and HSMI, it may be difficult to differentiate between the 2 diseases. Because of the similarity of lesions in the spongy myocardium, HSMI is likely to mask CMS. Incidences of sudden death in HSMI outbreaks may be the result of such co-occurrence, but it may be just as likely that severe damage to the spongy myocardium will cause a similar mortality pattern regardless of cause.

Skeletal muscle lesions are present in both HSMI and PD (Ferguson et al. 1986, Murphy et al. 1992). In HSMI, as well as in PD (Murphy et al. 1992), the red muscle tissue is most severely affected. Only limited lesions in skeletal muscle have been described from fish with CMS (Ferguson et al. 1990).

Widespread multifocal hepatocytic necrosis, as seen in HSMI, has not been reported in PD. In CMS, degeneration and necrosis of hepatocytes has been observed distal to hepatic vessels (Ferguson et al. 1990). In HSMI, liver necroses are observed both proximal and distal to hepatic vessels.

One of the major histopathological findings in PD is an acute necrosis of acinar pancreatic cells, followed by severe or complete loss of exocrine pancreatic tissue (Munro et al. 1984). The inflammatory response is minimal (Munro et al. 1984, Ferguson et al. 1986, McLoughlin et al. 1995, Murphy et al. 1995). Investigations of PD in Norwegian salmon farms (A. B. Olsen pers. comm.) suggest that the process of pancreatic damage is prolonged and that the pancreatic tissue regenerates at a later stage than described by Desvignes et al. (2002). In PD outbreaks in Norway, one would therefore expect pancreatic lesions to occur concurrently with heart and muscle lesions. Fish sampled from outbreaks of HSMI have intact pancreatic tissue.

In conclusion, the present work shows that HSMI is histopathologically distinguishable from PD and CMS, although there are similarities that challenge correct diagnosis. To increase the accuracy of the diagnosis, more work has to be done in order to establish the exact aetiology of HSMI.

Acknowledgements. Sincere thanks to A. B. Olsen at the National Veterinary Institute in Bergen, Norway, for valuable participation in sampling and diagnostics during the 1999 outbreak.

\section{LITERATURE CITED}

Boucher P, Raynard RS, Houghton G, Baudin Laurencin F (1995) Comparative experimental transmission of pancreas disease in Atlantic salmon, rainbow trout and brown trout. Dis Aquat Org 22:19-24 
Bruno DW, Poppe TT (1996) A colour atlas of salmonid diseases. Academic Press, London, p 140-141

Carlton WW, McGavin MD (1995) Pathology of the cardiovascular system. In: Duncan LL (ed) Thomson's special veterinary pathology. Mosby, St. Louis, p 175-208

Castric J, Baudin Laurencin F, Bremont M, Jeffroy J, Le Ven A, Bearzotti M (1997) Isolation of the virus responsible for sleeping disease in experimentally infected rainbow trout (Oncorhynchus mykiss). Bull Eur Assoc Fish Pathol 17: 27-30

Crockford T, Menzies FD, McLoughlin MF, Wheatley SB, Goodall EA (1999) Aspects of the epizootiology of pancreas disease in farmed Atlantic salmon Salmo salar in Ireland. Dis Aquat Org 36:113-119

Desvignes L, Quentel C, Lamour F, Le Ven A (2002) Pathogenesis and immune response in Atlantic salmon (Salmo salar L.) parr experimentally infected with salmon pancreas disease virus (SPDV). Fish Shellfish Immunol 12:77-95

Falk K, Dannevig BH (1995) Demonstration of infectious salmon anaemia (ISA) viral antigens in cell cultures and tissue sections. Vet Res 26:499-504

Ferguson HW, Roberts RJ, Richards RH, Collins RO, Rice DA (1986) Severe degenerative cardiomyopathy associated with pancreas disease in Atlantic salmon, Salmo salar L. J Fish Dis 9:95-98

Ferguson HW, Poppe T, Speare DJ (1990) Cardiomyopathy in farmed Norwegian salmon. Dis Aquat Org 8:225-231

Fijan N, Sulimanovic D, Bearzotti M, Muzinic D, Zwillenberg LO, Chilmonczyk S, Vautherot JF, de Kinkelin P (1983) Some properties of the Epithelioma Papulosum Cyprini (EPC) cell line from carp Cyprinus carpis. Ann Virol 134: 207-220

Grotmol S, Totland GK, Kryvi H (1997) Detection of a nodavirus-like agent in heart tissue from reared Atlantic salmon Salmo salar suffering from cardiac myopathy syndrome (CMS). Dis Aquat Org 29:79-84

Houghton G (1994) Aquired protection in Atlantic salmon Salmo salar parr and post-smolts against pancreas disease. Dis Aquat Org 18:109-118

Kent ML, Elston RA (1987) Pancreas disease in pen-reared Atlantic salmon in North America. Bull Eur Assoc Fish Pathol 7:29-31

Kongtorp RT, Kjerstad A, Taksdal T, Guttvik A, Falk K (2004) Heart and skeletal muscle inflammation in Atlantic salmon Salmo salar L.: a new infectious disease. J Fish Dis (in press)

Lannan CN, Winton JR, Fryer JL (1984) Fish cell lines: establishment and characterization of nine cell lines from salmonids. In Vitro 20:671-676

McLoughlin MF, Nelson RT, McCormick JI, Rowley H (1995) Pathology of experimental pancreas disease in freshwater Atlantic salmon parr. J Aquat Anim Health 7:104-110

McLoughlin MF, Nelson RT, Rowley HM, Cox DI, Grant AN (1996) Experimental pancreas disease in Atlantic salmon Salmo salar post-smolts induced by salmon pancreas disease virus (SPDV). Dis Aquat Org 26:117-124

Editorial responsibility: David Bruno,

Aberdeen, UK
McLoughlin MF, Nelson RT, Rowley HM, Cox DI, Grant AN (1997) The development of an experimental model of pancreas disease in Atlantic salmon (Salmo salar) post-smolts. Fish Vaccinol 90:467-467

McLoughlin MF, Nelson RN, McCormick JI, Rowley HM, Bryson DB (2002) Clinical and histopathological features of naturally occurring pancreas disease in farmed Atlantic salmon, Salmo salar L. J Fish Dis 25:33-43

Munro ALS, Ellis AE, McVicar AH, McLay HA, Needham EA (1984) An exocrine pancreas disease of farmed Atlantic salmon in Scotland. Helgol Meeresunters 37:571-586

Murphy TM, Rodger HD, Drinan EM, Gannon F, Kruse P, Korting W (1992) The sequential pathology of pancreas disease in Atlantic salmon farms in Ireland. J Fish Dis 15:401-408

Murphy TM, Drinan EM, Gannon F (1995) Studies with an experimental model for pancreas disease of Atlantic salmon Salmo salar L. Aquac Res 26:861-874

Nelson RT, McLoughlin MF, Rowley HM, Platten MA, McCormick JI (1995) Isolation of a toga-like virus from farmed Atlantic salmon Salmo salar with pancreas disease. Dis Aquat Org 22:25-32

Poppe T, Rimstad E, Hyllseth B (1989) Pancreas disease in Atlantic salmon (Salmo salar) postsmolts infected with infectious pancreatic necrosis virus (IPNV). Bull Eur Assoc Fish Pathol 9:83-85

Poppe TT, Breck O (1997) Pathology of Atlantic salmon Salmo salar intraperitoneally immunized with oil-adjuvanted vaccine. A case report. Dis Aquat Org 29:219-226

Raynard RS, Houghton G, Munro ALS (1992) Pancreas disease of Atlantic salmon: proceedings of a European Commission Workshop. Scottish Office Agriculture Report, No. 1. Scottish Office Agriculture and Fisheries Department, Aberdeen, p 2-4

Rodger HD, Turnbull T (2000) Cardiomyopathy syndrome in farmed Scottish salmon. Vet Rec 146:500-501

Rodger HD, Murphy TM, Drinan EM, Rice DA (1991) Acute skeletal myopathy in farmed Atlantic salmon Salmo salar. Dis Aquat Org 12:17-23

Rodger HD, Turnbull T, Richards RH (1994) Myopathy and pancreas disease in salmon-a retrospective study in Scotland. Vet Rec 135:234-235

Villoing S, Bearzotti M, Chilmonczyk S, Castric J, Bremont M (2000a) Rainbow trout sleeping disease virus is an atypical alphavirus. J Virol 74:173-183

Villoing S, Castric J, Jeffroy J, Le Ven A, Thiery R, Bremont M (2000b) An RT-PCR-based method for the diagnosis of the sleeping disease virus in experimentally and naturally infected salmonids. Dis Aquat Org 40:19-27

Weston JH, Welsh MD, McLoughlin MF, Todd D (1999) Salmon pancreas disease virus, an alphavirus infecting farmed Atlantic salmon, Salmo salar L. Virology 256: 188-195

Wolf K, Quimby MC (1966) Lymphocystis virus: isolation and propagation in centrarchid fish cell lines. Science 151: 1004-1005

Submitted: September 29, 2003; Accepted: March 1, 2004

Proofs received from author(s): May 3, 2004 